\title{
Hydropower and the geopolitics of renewable energies in the Amazon Basin
}

\author{
Carlos Potiara Castro
}

${ }^{I}$ Center for Amazonian Studies, Center for Advanced Multidisciplinary Studies, University of Brasília, Brazil.

\begin{abstract}
This article aims to reflect on the strategic importance of hydroelectric energy generated in the Amazon region for the interconnected Brazilian system. Its quantification shows a regional potential for higher energy generation compared to the current production of pre-salt oil. We consider this issue from the perspective of the geopolitics of renewable energy that brings new and relevant elements. In this article, the analytical framework focuses on path-dependence, smartgrids and energy-intensive societies and their energy security policies. As a result, we observe that in the current configuration, the advent of renewable energies can be an additional element of a long-term economic specialization of the Amazon, with worrying consequences from a socio-environmental perspective.
\end{abstract}

Keywords: Path dependence; Energy security policies; Energy-intensive societies; Amazonia.

São Paulo. Vol. 24, 2021

Original Article

DOI: http://dx.doi.org/10.1590/1809-4422asoc20200129r1vu2021L2AO 


\section{1 - Introduction}

There is a wide range of reasons why the discussion around energy historically links with geopolitics. The most recent mentions the transition process to new renewable energies $^{1}$. The consequences of this transition are relevant to the power relations between states and the economy, as it will lead to a reduction in dependence on fossil energy and will favour conflicts that accompany it (MATUTINOVIĆ, 2009, p. 4252). The geopolitics of renewable energies, an area of growing interest, is established in academia, especially since the 2010s, with a significant increase in scientific publications. Some of its authors affirm that the need for energy independence was one of the main reasons for financing technological research to make new renewable sources viable. Nevertheless, the dependence does not disappear completely, but it is reduced in intensity and transitioned to the supply of other commodities, such as rare-earth minerals.

The accelerated transformation of the Brazilian electricity matrix, in which wind production becomes the second-largest source of supply, surpassing thermoelectric plants, and where the solar sources grow at three-digit rates per year, is an example of an extensive and global phenomenon. The system management of integrated electricity transmission increases with new renewable energy sources, usually established near consuming regions. With this configuration, hydroelectric generation and the thermal power plant become strategic items since they act as a steady power and system battery, complementing the supply of renewables that show time differences in power generation and year-on-year seasonality.

The Amazon is the largest of the existing rivers, and its drainage basin is one of the most important, just below that of the Gulf of Mexico and the Caribbean (WRI, 2005). It has the unique feature of having its economic development configured without coherence with its main course. Coordinated actions and development strategies come from a southeastern society, essentially of a River Plate basin ethos. Somehow exogenous, these actions are strange, which led to geopolitical thinking translated into an energy security policy and an economic specialization.

This article aims to critically discuss the exporting role of hydroelectric power in the Amazon region. To this end, our research is developed based on three fields of knowledge: the geopolitical importance of energy, the transition to renewable energy sources and environmental policy.

This paper contains four sections. The first one addresses the advent of renewable energies, the concept of path dependence and the economic and social consequences of lock-in in a certain technology in the medium and long term. It will also focus on the instability of closed systems and energy security policies.

For the second and third sections, the theoretical contribution of the geopolitics of renewables will be addressed, as an expression of interterritorial relations, which, although it brings new variables, does not prevent the formation of energy-intensive societies, as well as an energetic populism, which broadly justifies the projection of force abroad, through instru-

1 - In this article, renewable sources refer to new sources: solar, wind, tidal, geothermal, and biomass, such as sugarcane bagasse. The hydroelectric source will be explicitly referred to. 
ments of command-and-control. In the last part, a planned energy assessment will be carried out between produced and exported energy from hydroelectric plants in the Amazon region, expressed as barrels of oil equivalent (BOE). The article focuses on its strategic role. These results depend on an extensive study of 76 individual energy plants.

In the conclusion section, possible scenarios for a region to become an energy resources exporter will be studied, articulating a geopolitical and socio-environmental perspective.

\section{2 - Path dependence and the political economy of energy}

The concept of path dependence axes on a specific institutional characteristic: such as the form of organization, the technical standard or economic development; is not based on current conditions but is formed by a sequence of previous decisions, each one leading to a different result (DAVID, 1985, p. 338; BERNARDI, 2012, p. 143; BALAZ; WILLIAMS, 2007, p. 39). It reappears vigorously in the scientific literature from discussions on the transition from the energy matrix to new renewable sources and the decarbonization of contemporary societies (FOUQUET, 2016, p. 2; FOXON et al., 2013, p. 146). This concept brings the perspective of locking power systems and highlights the importance of the past cumulative decisions and choices made to understand the difficulties to be overcome in the transition to renewables. Thus, this vision states that elements of a system co-evolve, which helps understand why this transition becomes so complex and does not depend only on the advent of new technologies (MOORE, 2003, p. 315). For this reason, Fouquet (2016, p. 2) argues that "lock-ins and path dependence urgently need to be better understood, their implications identified, and strategies to deal with them formulated.".

Energy systems are subject to a prominent path dependence on a long-term trajectory, often over 50 years, due to their infrastructure, technology and market characteristics. Decisions leading to adopting a given energy source have a complex origin, often lost over time while bequeathing steady forms of economy and social organization (RUTTAN, 1997, p. 1523; FOXON et. 2013 p. 147). There are several illustrative examples of the difficulties of escaping technological lock-in. Take, for example, the process of overcoming the standard gasoline-propelled motor vehicle, consolidated between 1905 and 1920, by the electric that emerges as its real competitor since the 2000s. The history of technology shows that between 1885 and 1905, three standards were vying for the public. In 1899, were sold in the United States 1,575 electric vehicles, 1,681 steam cars and 936 gasoline. This case suggests a complex situation, in which "the interaction of several economic and technical factors gave the gasoline car a decisive advantage between 1900 and 1905." (COWAN; HULTEN, 1996, p. 66). These were factors not fully controlled by the agents in this arena. Nevertheless, the configuration was such that it began to change only a century later. Another complex case occurred with the adoption of a technology standard for electrical production from nuclear power plants. Light-water reactors for uranium exploitation are considered inferior to those that adopt other technologies. However, they have come to dominate $80 \%$ of the market of power plants built around the world for historical reasons (COWAN, 1990, p. 545; DAVID, 1985, p. 336; CAVALHO, 2014, p. 29). 
Facing the challenges of energy transition and societies decarbonization in response to climate change, decisions taken in the past concerning technologies and energy sources have a considerable force of inertia, which prevents them from being transformed quickly and without complexity (RAMAN, 2013, p. 173; RUOTSALAINEN, 2017, p. 232). For this reason, the combination of power generation options, in the era of the transition to renewables, needs to be defined at the same time as the desired long-term development model, especially since there are tangible human implications, such as the necessary connection to the network of 850 million people who still live without access to it (IRENA, 2019; CASTRO, 2017, p. 5, 2019a).

The production and supply of energy, throughout the 20th century, due to the construction of a set of works, co-evolved jointly with the sector's technology, the formation of human capacities, the structuring of management bureaucracies and transaction market (FOXON et al., 2013, p. 148; ANSAR et al., 2014, p. 43). In this context, the construction of power generation infrastructures, such as hydroelectric power plants, promotes a sudden increase in supply and, therefore, it generally depends on demand induction plans (ANSAR et al., 2014, p. 47), such as granting subsidies to productive sectors that guarantee the consumption of the generation surplus (NICOLINI; TAVONI, 2017, p. 413). The growth of household income, plus policies to induce consumption, leads, over time, to a system trap, leaving few options for changing trajectory. Graph 1 below illustrates this by highlighting the role of subsidizing policies in total energy consumption.

Graph 1: Relationship between per capita consumption (y-axis), expressed in equivalent tons of oil, by per capita subsidy (x-axis) in 50 countries, in dollars

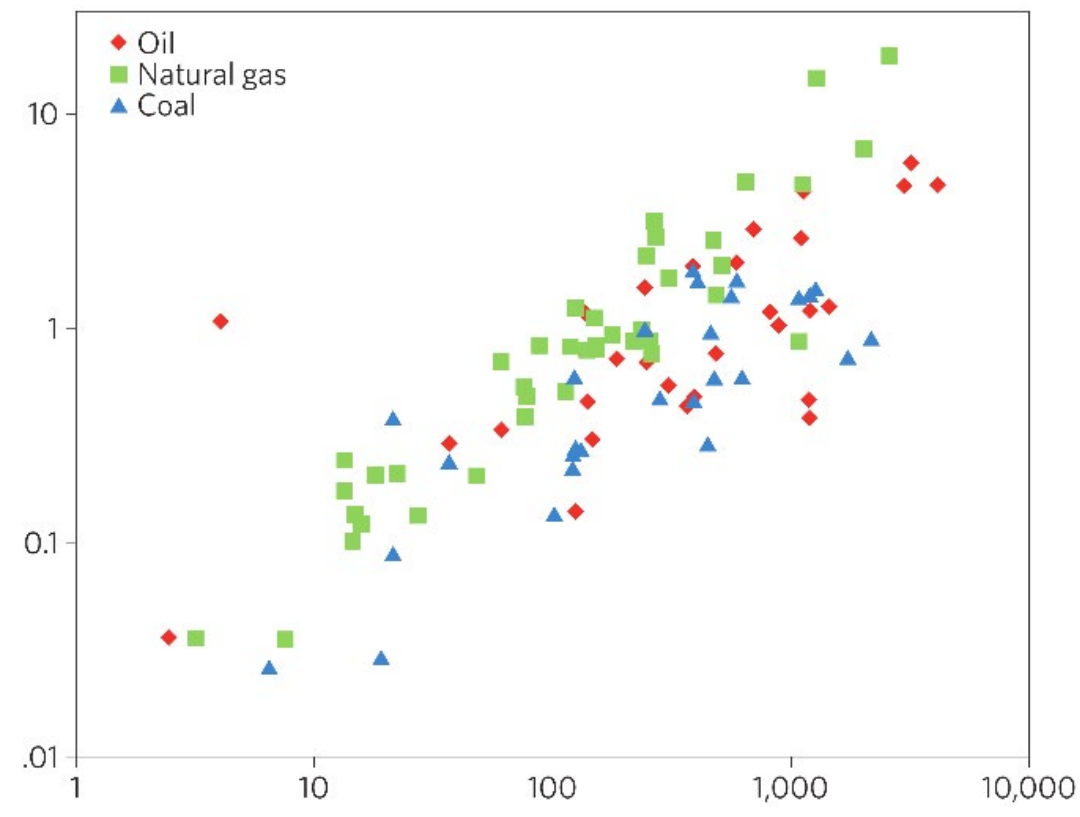

Source: British Petroleum, 2015, apud. Fouquet, 2016. 
Thus, we see the rise of a systemic vulnerability, which will lead to the institutionalization of energy security policies ${ }^{2}$. These policies can focus on supply, demand, or a combination of both. New technologies, or the update of existing consumer units, and the transformation of ways of life in a society, can achieve a decrease in energy demand. (CAPELLÁN-PÉREZ et al., 2017, p. 761). However, the history of economic development shows that human societies have dealt more frequently with the scarcity of energy resources by increasing supply through new reserves exploitation (FOUQUET, 2016, p. 2). At this point, Högselius and Kaijser state that:

Energy import-dependent countries have historically pursued two broad strategies for coping with energy dependence and the vulnerabilities it generates. The first and most obvious has been to develop domestic energy sources. The second has been to find ways to manage - rather than to reduce - energy imports.

As a result, one can understand the actions of nations considered the most dynamic poles of global capitalism as guarantors of the international flow of energy commodities $(\mathrm{MO}$ HAPATRA, 2016, p. 684). Most visible by its extent, geopolitical operations in the Middle East to ensure the continued supply of oil to the international market are very concrete official energy security policies. And as such, they were the subject of reflection and received budget funds for their implementation (DELUCCHI; MURPHY, 2008, p. 22543).

Energy became, in the 19th century, for the first time in history, a geostrategic issue for national governments, for important economic agents such as large corporations, as well as for societies (MATUTINOVIĆ, 2009, p. 4251). Immobility in forms of use of energy resources increases the feeling of imminent scarcity, which generates violence in energetic-intensive Fordist societies (HUBER, 2013, p. 181). And it is in the intertwining between dependence on a trajectory and systemic vulnerability that command-and-control policies appear, which is one of the reasons why the transition to renewables has become so desirable for several actors in the geopolitical arena, understood as a power policy in the "phenomenon of space" (CORREIA, 2018, p. 95; HÖGSELIUS; KAIJSER, 2019, p. 443).

\section{3 - Geopolitics of renewables, smart grids and kinetic energy storage}

An analytical field in development, the geopolitics of renewable energies, gains definition in the 2010s by selecting the main points of a knowledge framework and its main strategic dimensions (OVERLAND, 2019, p. 37). Since its inception, authors from research institutions in developed countries but with less geopolitical weight led this field, especially the Scandinavians, the Netherlands and Spain. This is due to the high research investment they injected in areas affecting energy security, a topic of vital interest for these countries with little capacity to influence a multilateralism marked by nuclear power (HÖGSELIUS; KAIJSER, 2019, p. 443).

2- Whether thermoelectric, nuclear or hydroelectric power plants, they are invariably the subject of national security plans for their protection, as well as oil regions and uranium deposits (FONTAINE, 2003, p. 87).

3 - These latest authors claim that a value between $0.2 \%$ and $0.6 \%$ of U.S. GDP was used in military actions abroad to ensure oil supply flow. 
As the economic and social transformations are not yet fully completed, this field produces prospective and comparative literature, which means its object is the historical transition of significant human consequences (RUOTSALAINEN et al., 2017, p. 231). The oil civilization transformed the world geography (HUBER, 2008, p. 106), its cities, people's ways of life and led to the emergence of new and broad economic sectors, such as service-sector and mass consumption. An initial performance framework for the geopolitics of renewable energy emerged from these transformations (SCHOLTEN; BOSMAN, 2016, p. 273).

Vakulchuk et al. $(2020$, p. 2) observed, in an extensive literature review of the scientific literature in this field, the existence of five essential topics. The first, and most often addressed, presents a discussion around the potential for reducing current conflicts arising from energy issues, thanks to the renewables transition. The second one underlines which countries and regions will win or lose and the positive or negative scenarios to be faced. The third one highlights the consequences of the spread of renewable energy to international relations, knowing the centrality of the energy agenda. And the last two points, pointed out by these authors, refer to new strategic areas: the essential materials for equipment construction, necessary for the generation of clean energy, as well as the possible cartel formation in the mining sectors of these elements (HACHE, 2016, p. 42), and the cybersecurity of the electrical system, which should be increasingly automated, therefore, susceptible to external attacks (SULLIVAN et al., 2017, p. 23).

Most authors agree that conflicts tend to diminish with the transition to renewables. Nevertheless, there are several factors in the game that need to get counted. Firstly, the oil will not cease to be the primer energy source in the medium term. Today, renewables only represent $4.05 \%$ of the total energy consumed and should not exceed 28\% by 2050 (BP, 2019; IRENA, 2019). Therefore, territorial issues related to oil persist (MOHAPATRA, 2016, p. 690; AUGÉ, 2014, p. 24). Moreover, territorial safety for energy transit also applies to renewable energies. From this perspective, Sullivan et al. affirm that "In case of a large-scale renewable energy production and transportation across borders in the form of electricity, the principle of territorial control will be similar to that for oil and gas pipelines." (2017, p. 41). In the same vein, Paltsev states that:

As with fossil fuels, transit countries in the electricity trade are crucial. Most of the geopolitical gamesinvolving natural gas (in Europe) are played not between buyer and seller but between a seller and a transit country (2016, p. 392).

On the other hand, Raman talks about the "fossilization of renewables", questioning the optimism of those who claim that renewables are intrinsically democratic and egalitarian and believe they "do not offer a free lunch, but rather a set of options that are vastly superior to fossil fuel or nuclear alternatives" (RAMAN, 2013, p. 178). Capellán-Perez et al. (2017, p. 774) state that there is a danger of "intensifying an imperialist geopolitics to conquer lands and seize resources from other countries" if the same social characteristics of energy use are maintained. Thus, there is a consensus the territory will continue to be 
a vital power element, even with the growth in the supply of renewable energy.

From a technological perspective, the large-scale establishment of renewables will lead to profound transformations in the energy market and the producer-consumer relations (PHUANGPORMPITAK; TIA, 2013, p. 286). They will require a distributed electrical network with new systemic equilibrium mechanisms, a transformation called "energy infrastructure with complex and adaptive sociotechnical systems" (SCHOLTEN; BOSMAN, 2016, p. 275). In addition to the massive power plants, consumers themselves become producers and energy prices fluctuate in real-time to reflect offer and demand peaks (PALTSEV, 2016, p. 392). From this angle, it will be the management of the network that will determine, firstly, the final price of energy and, secondly, the success of the renewables' adoption on a larger scale (HACHE, p. 39, 2016). It will be necessary to use smart grids, instead of an inflexible system, using digital technology for control automation, continuous monitorization and optimization of the distribution system, to meet the needs of network management (ARCIA-GARIBALDI et al., 2018, p. 298; PHUANGPORMPITAK; TIA, 2013, p. 284).

What justifies the implementation of smart grids is the intermittent production of renewable energy at every moment of the day (FOXON, 2013, p. 155). Wind, solar or tidal power generation have this inherent characteristic of not providing steady energy, and the one generated from biomass faces an annual seasonality (OVERLAND, 2019, p. 38). Therefore, to accommodate a higher percentage of renewable energy, the electricity grid will need large amounts of conventional energy reserves and a consequent energy storage capacity (BARBOSA et al., 2016, p.100). To help respond to the intermittence in the energy supply by renewables, it will mostly be conventional thermal or nuclear power plants themselves, in addition to large lithium batteries that will do the job.

The clean backup option, which enables renewables use, is the energy generated by hydroelectric plants (PÉREZ-ARRIAGA et al., 2016, p. 766; ANSAR et al., 2014, p. 48). Its reservoirs function as large-scale kinetic energy storage (HUNT, 2020, p. 2; IMMENDOERFER et al., 2017, p. 231), which can be transformed into electricity quickly, feeding the integrated system with steady energy. It is in this context that the Norwegian project, provider of storage service, emerges. It could become the European "green battery", with the forecast of transport by submarine cables of part of its national hydroelectric production, one of the largest worldwide (GULLBERG, 2013, p. 616). This project could modify the Norwegian geopolitical status at a regional level, increasing its bargaining power on the energy agenda (SCHOLTEN et al., 2014, p. 279).

The running Amazon hydropower plants, as well as their immense potential to be used, will play an even more essential role in Brazilian energy geopolitics (TAVARES et al., 2006, p. 109). Dams located in the Amazon have a high environmental liability (FEARNSIDE, 2015b, p. 16; CORREAA, 2016, p. 234; FLEURY; ALMEIDA, 2013, p.142), which mainly results from a petrified relationship with the country's River Plate basin regions, which direct regional policies (BERMANN, 2012, p. 6). Addressing the Belo Monte hydroelectric plant construction, Nascimento and Castro speak of the "creation of territories of exception" where the legal norm does not apply (2017, p. 141). Paradoxi- 
cally, one principal source that will enable the implementation of large-scale renewable generation projects will be a set of works that will submerge standing forests, lands of indigenous peoples and traditional populations (FEARNSIDE, 2015a, p.42; CASTRO, 2004, 2008a, 2011).

Behind the large-scale implementation plans of renewable energy generation projects are development projects designed to increase the demand of a society that intensively uses energy assets. Thus, a reflection around these societies is necessary and on their institutions and energy security policies.

\section{4 - Energy-intensive societies and national energy security policies}

Historically, the growth of energy use intensity occurs in socio-technological systems in which there is a co-evolution of knowledge about the use of available sources and the adaptation of society to its use (CARVALHO, 2014, p. 26; RUOTSALAINEN et al., 2017, p. 237). The oil age interlaces with the twentieth century and the accelerated transformation process of human societies on a planetary scale. The social adaptation to a new technological reality occurs along with the structuring of socio-political agreements between various social actors in a transformed environment.

North America was considered, in its heyday, as a model for other societies. Fordism, which arises in this country, turned means of transport into consumer goods. Nevertheless, through the New Deal coalition, dominant on the political scene until the late 1960s, workers gained welfare resources, mainly based on mass consumption and abundant energy. On this point, Matthew Huber states that:

Ironically, although Fordism was institutionalized through the public solidarity of New Deal liberalism, it helped to produce a very privatized geography of social reproduction (...). This appearance of autonomy was fueled by the massive consumption of oil products (...). The crucial role of oil was to promote an extensive spatiality of mass consumption, which was called "mobile privatization": automobility; private single-family housing; spacious gardens and backyards; and extensive distances between home, work, commercial areas and leisure spaces (2013, p. 179).

We can, therefore, refer to an energetic populism in which the rich supply of oil derivatives helps to sustain a social agreement, with at its pole a foreign policy of energy security (MOHAPATRA, 2016, p. 694). Even though ordinary people of such a society cannot perceive the consequences of force projection policies abroad, they still benefit from them. It seems like, despite the loss of individual freedom in an alienated and massified society (HUBER, 2008, p. 108), there still exists welfare promoted by the abundance of available energy.

Brazil becomes energy-intensive in this context of incorporation of a societal model around the world (CASTRO; FERREIRA, 2013, p. 260; CASTRO, 2008b, 2019b). The economic growth from the 2000s to mid-2010 was accompanied by an internal increase 
in energy demand, both electric and fossil. It is a trend observed globally, as shown in Graph 2, below. The growth in energy demand largely emerged from the discoveries of new oil deposits and thermoelectric plants construction. Nonetheless, for supply planning in the country, hydroelectricity is an essential component. Most of the increase in electricity came from dams in the Amazon Basin.

Graph 2: Change in GDP and energy consumption in the world 1998-2007

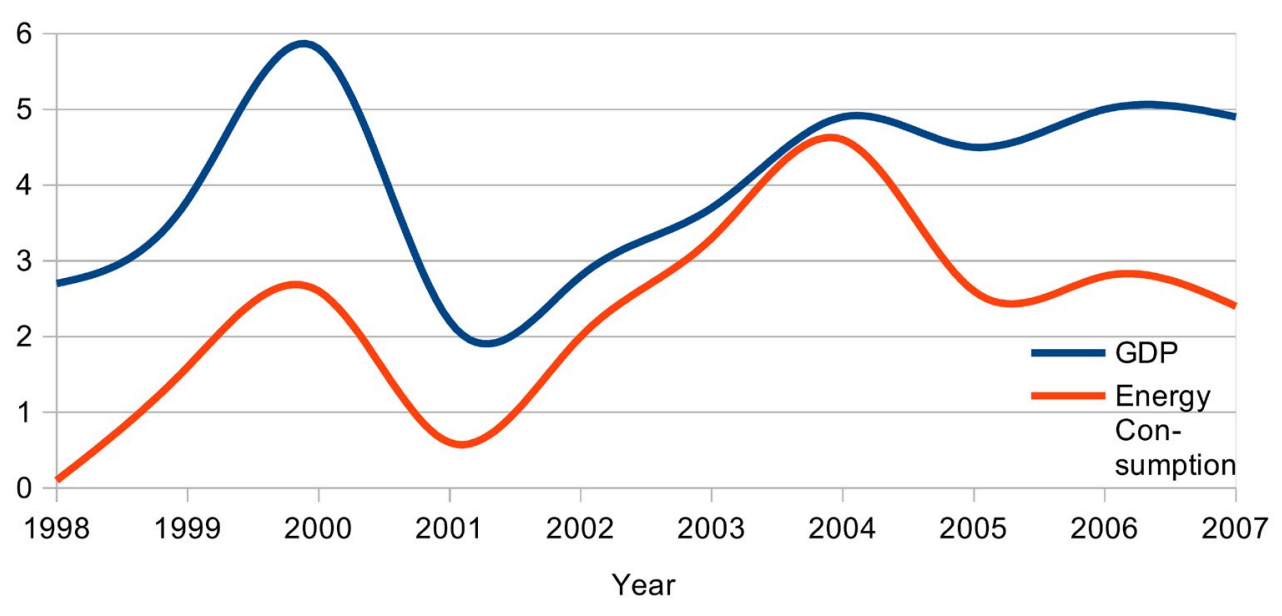

Source: British Petroleum, 2008.

It is worth remembering that the current Amazonian policies around energy and occupation were designed mainly during the authoritarian military governments. While the internal geopolitics of the military (PROST, 2000, p. 4) referred to the Amazon as a marginal Brazil (CASTRO, 2019, p. 131, 2006), the planning of its occupation, outlined in the 2nd National Development Plan of 1974, "established as a priority to reduce, at an accelerated pace, country's dependence on external energy sources" (TAVARES et al., 2006, p. 106). The objective was to take advantage of the Amazon hydroelectric potential keeping up with the main vectors of deforestation. The application of public policies induction served to guarantee higher consumption through subsidies for electrointensive industries destined for exportation (FEARNSIDE, 2015b, p. 113). The result was a clear dependence on a long-term trajectory.

Amazonian geopolitics is an element of the military legacy, whose study helps understand what is currently going on in the region. It created a strangeness with the local space since it verbalized River Plate basin perspectives on another territory (RAVENA et al., 2019, p. 141) and defined the region with an economic and energetic role (PROST, 2000 , p. 28). Amazon's main dams follow the same direction as the deforestation vectors, either those that destroyed the forests near Marabá and Tucuruí in the Tocantins river, in 
the Xingu river in the Transamazon region where we can find the Belo Monte plant, or those that advance in the area divided by the BR-163 road, where the construction of São Luiz do Tapajós is planned (FEARNSIDE, 2015a, p. 428). It is a set of public policies that arise "under the stigma of energy security" (BERMANN, 2012, p. 7) and that generated the establishment of bureaucracies for command-and-control instruments, specific to the Amazon region, since the beginning of the military dictatorship (PROST, 2000, p. 5).

These policies translate as a continuum state's action in the region, even during the democratic period. Table 1 lists a set of public policies with these characteristics. For the last eight years, four of them have been edited or updated through presidential decrees. The permanent Office established in 2013, under Dilma Rousseff, during social protests against the construction of the Belo Monte hydroelectric plant (RAVENA et al., 2019, p. 147), aimed to act specifically in the Legal Amazon. Its purpose was, among others, to "guarantee law and order" (BRASIL, 2013). In 2019, the current president launched the Barão do Rio Branco project (APIB, 2019; FERREIRA, 2010, p. 203) for the left riverbank of the Amazon Basin, resuming the plan of the military dictatorship to replicate the pattern of occupation of the right riverbank. As a continuous act, the decree of 2013 is replaced in 2019 by a vague and subject to interpretations content one, with the same command-and-control instruments. The current government modifies the National Council for the Legal Amazon (BRASIL, 2020b), which is currently coordinated by a general and has no less than 23 military officers as full and alternate members.

Table 1: Specific command-and-control instruments for the Amazon region

\begin{tabular}{|l|l|l|}
\hline & Public policies and projects & Year \\
\hline 1 & The Military Geopolitical project & 1968 \\
\hline 2 & 2nd National Development Plan and its developments & 1974 \\
\hline 3 & The Amazon Cooperation Treaty Organization & 1978 \\
\hline 4 & $\begin{array}{l}\text { The "Calha Norte" Program: occupation the left riverbank of the } \\
\text { Amazon }\end{array}$ & 1985 \\
\hline 5 & Amazon Surveillance System and Amazon Protection System & 2002 \\
\hline 6 & $\begin{array}{l}\text { Permanent Office for Coordination and Technical Integrated Mana- } \\
\text { gement for the Protection of the Environment (CGI-MA) }\end{array}$ & 2013 \\
\hline 7 & Barão do Rio Branco Project (update of "Calha Norte") & 2019 \\
\hline 8 & "Militarization" of the Legal Amazon National Council & 2020 \\
\hline
\end{tabular}

Source: Research data; APIB, 2019; Brazil, 2013, 2020b.

This activity causes pressure on the society and the Amazonian space from national institutions better representing consumer centres, same as with other regions producing energy sources. 
The seven largest hydroelectric producers worldwide 4 - Brazil being the third one-add up to $61 \%$ of the world's installed capacity of 1,245.8 GW (Empresa de Pesquisa Energética ${ }^{5}$ - EPE, 2019a, p. 31). Most of the hydroelectric power potential yet to be explored is in Latin America and Asia. In this context, in Brazil, about $50 \%$ of the expansion of electricity production may come from hydroelectric sources in the future (EPE, 2019b, p. 184). Moreover, of the hydroelectric potential to be used, more than 70\% are in the Amazon Basin (ANEEL, 2008, p. 57). It will take place in a context where, as in other regions producing energy sources, there will continue to be pressure from consumer regions on the Amazonian society and space. It might predict the history of the 21st-century in energy geopolitics.

\section{5 - Sizing of hydroelectric resources}

The quantification of the Amazon hydropower generation in barrels of oil equivalent, universally used in the geopolitical literature, allows us to see its strategic role in the national productive system and society. For this assessment, it is necessary to define a generating technology powered by fossil fuel and equalize the outputs. Due to their flexibility to generate steady energy, thermal power plants powered by natural gas can play this role, even if they are more efficient than the average Brazilian fossil fuel generating park.

The literature on hydroelectric plants has a terminology appropriate to its technology. The hydroelectric potential of a river basin, determined with a government act, depends on technical studies (EPE, 2019b, p. 124). It has two components: the inventoried potential that accurately measures the exploitations available for future projects and the potential harnessed by completed and operating plants.

The hydroelectric potential indicates the maximum generation capacity at a hypothetical peak moment. Besides, the energy assured corresponds to the average of the one generated. It corresponds to the contracted power that a hydroelectric power plant delivers to the interconnected national distribution system, and it is measured annually. Therefore, it equates to a percentage of hydroelectric potential.

The difference between the guaranteed energy produced by hydroelectric plants and the average consumption of the Amazon region will give us a dimension of energy exportation capacity and the geostrategic role it plays.

The conversion of the generated energy in megawatts to the barrel of oil equivalent unit counts the average thermal efficiency of the U.S. natural gas plants of 2014 as a parameter (EIA, 2019: 168). The efficiency of its gas-generating park must be higher than the national one. It comes from a fast evolution in the efficiency level at gas-fired thermoelectric plants, through new technologies adoption, and by intense financial investments in the national energy sectors. Thus, to avoid deviations from excess ${ }^{6}$, the

4 - Respectively, China (332 GW), United States (102.7 GW), Brazil (96.9 GW), Canada (80.3 GW), Russia (51.2 GW), Japan (50.1 GW) and India (47.5 GW).

5 - Energy Research Company is a Brazilian public institution aimed at producing technical and scientific data on energy.

6 - It would be ethically correct to avoid overstatements over the results since there is no updated average efficiency number of the Brazilian energy park. 
average efficiency of $43.2 \%$ was adopted as a parameter in our calculations, i.e., 7,907 Btus $^{7}$ for every generated kilowatt-hour.

The methodology adopted in the research eliminates the small hydroelectric plants and includes the plants of the Araguaia-Tocantins river basin and those from northern Mato Grosso, within tributaries of the Amazon Basin.

The hydroelectric potential of the Amazon Basin is far from being determined since inventories from Negro, Trombetas, Purus, Acre and Juruá rivers are absent, in addition to the Solimões - Amazonas main course itself. The official measurements of hydroelectric power potential follow the progress of the main vectors of deforestation. Table 2 below shows the total potential and the daily production of hydroelectric plants in the Amazon Basin, in MWh and barrels of oil equivalent.

Table 2: Sizing hydroelectric production in the Amazon Basin and conversion to barrels of oil equivalent.

\begin{tabular}{|l|l|l|l|}
\hline & & MWh & $\begin{array}{l}\text { Barrels of oil/ } \\
\text { Day }\end{array}$ \\
\hline a & The hydroelectric potential of the Amazon Basin & $134.184,00$ & $3.292 .887,36$ \\
\hline b & $\begin{array}{l}\text { Calculated guaranteed energy of hydroelectric } \\
\text { potential }\end{array}$ & $72.338,60$ & $2.399 .832,90$ \\
\hline c & Hydroelectric potential of operational HPP & $36.204,91$ & $1.201 .097,89$ \\
\hline d & Guaranteed energy of operational HPP & $20.056,03$ & $665.358,80$ \\
\hline e & Average consumption of the Amazon Basin ${ }^{9}$ & $3.813,03$ & $126.497,22$ \\
\hline f & Available for export & $16.243,00$ & $538.861,53$ \\
\hline
\end{tabular}

Source: Research calculations, EPE, 2019b, p. 152; Brazil, 2020a, pp. 1 and 9.

Comparatively, the physical guarantee of the plants in operation, expressed in barrels of oil equivalent, is equivalent to the daily production of oil from a country like Egypt. The assured generated energy of 2,399,832.90 barrels of oil would approach Brazil's energy production, with the pre-salt energy source, if exploited all hydroelectric potential, as shown in Table 3, below (BP, 2019, p. 16). Even more significant is the result of available energy assessment to be exported in barrels of oil equivalent, which would place the region as the 15th largest exporter worldwide, between Azerbaijan and Algeria.

The water source represented $80 \%$ of the national electricity generation in 2017 (EPE, 2018, p. 5). Hydroelectricity is considered a renewable source and does not suffer

7 - British Thermal Unit

8 - Hydroelectric Power Plant

9 - The calculated consumption corresponds to the sum of consumption in the northern region, the Tocantins state and part of Mato Grosso, proportional to the average of bathed municipalities by tributaries of the Amazon Basin. 
from exhaustion predictions in the Hubbert curve for fossil resources (MATUTINOVIĆ, 2009 p. 4255). And as stated by the EPE, "in the current conjuncture of insertion of variable renewable energy sources, such as wind and solar, of an intermittent nature, the importance of hydroelectric plants with reservoir increases for the operation and safety of the system" (2018, p. 14).

Table 3: Largest global oil producers, including the Amazon

\begin{tabular}{|l|l|l|}
\hline & Country & $\begin{array}{l}\text { Millions of Barrels } \\
\text { per day }\end{array}$ \\
\hline 1 & USA & 15.311 \\
\hline 2 & Saudi Arabia & 12.87 \\
\hline 3 & Russia & 11.438 \\
\hline 4 & Canada & 5.208 \\
\hline 5 & Iran & 4.715 \\
\hline 6 & Iraq & 4.614 \\
\hline 7 & United Arab Emirates & 3.942 \\
\hline 8 & China & 3.798 \\
\hline 9 & Kuwait & 3.049 \\
\hline 10 & Brazil & 2.683 \\
\hline 11 & Amazon Basin & $2.399^{10}$ \\
\hline 12 & Mexico & 2.068 \\
\hline
\end{tabular}

Fonte: Research calculations; BP, 2019, p. 16.

In this context, the hydroelectricity generated in the Amazon may characterize the region as a vital internal exporter of energy, resulting from its geostrategic position for the productive system and the national society.

\section{5 - Conclusion}

This article aimed to observe the transition to renewable energies, focusing on three main elements. Firstly, the difficulty of achieving a smooth shift from fossil to a diverse set of new energy production forms. There are intimate relationships that are hard to ignore, such as technology, the productive sector, society, and the regulatory system, in a path dependency, whose original meaning has often shed in history. This relationship also imposes room for manoeuvre reduction for in-depth modifications in an energy system, thus constituting a clogging in options.

In a second perspective, the article presents the geopolitics of renewables. As we have seen, it is a prospective thought about processes that are still consolidating or will 
emerge soon. Among the various discussed elements, there is the prospect of reducing armed conflicts that originated in the intensive use of petroleum derivatives. Nonetheless, the more relevant topic to this research is the technical issue that this field discusses. The generation of energy with renewables, disseminated in a distributed network, has hundreds of production units that interconnect to meet consumption at a given time. The administration of smart grids becomes strategic in this way, especially if there are cross-border exchanges. The management of this network might help predict the natural variation of renewables' production. Battery usage, thermoelectric or hydroelectric plants could ensure the supply of steady energy and avoid interruptions. Thus, the storage of energy in dams, to sustain the interconnected systems of other countries and regions, becomes a geostrategic issue according to the specialized literature.

The third element addressed is the advent of societies that constitute themselves as great users of energy. It is a relevant issue to discuss. From a geopolitical perspective, without a change in their nature, present fossil energy problems are hard to overcome. The emergence of what we can call an energetic populism tended to carry out external projections of strength to ensure the abundance of internal energy and a type of social welfare that constituted an agreement between the productive, labour and government sectors. However, it is the logic behind this society model that generates energy security policies through command-and-control tools. Thus, the analysis focuses on the position the Amazon region will occupy as a steady energy supplier. Considering the present occupation of the right riverbank, through "internal geopolitics", by the military at power, uses command-and-control instruments specific for this region, the issue gains even more weight. From the beginning, the Amazon hydroelectric production was a geostrategic element.

Besides these topics, the article presents the assessment of hydroelectric production in the Amazon, converted into barrels of oil equivalent, or the natural unit of discussion in energy geopolitics. With these figures, it was possible to measure the importance of energy export to the rest of the country, equivalent to great exporting countries.

Thus, this article sought to raise questions for a detailed debate on the impacts of the energy transition, interpreted by the field of renewable geopolitics, on regions with high energy storage capacity. In the Amazon Basin case, it may constitute another socio-environmental problem. It will encourage the main vectors of the vegetation cover transformation and destruction in the standing forest. It is something unexpected, given the promises brought by renewables, of transforming contemporary societies. 


\section{References}

AGÊNCIA NACIONAL DE ENERGIA ELÉTRICA. Atlas de energia elétrica do Brasil. Brasília: ANEEL, 2008, 236 p.

. Cadernos Temáticos: Energia Assegurada. Brasília: ANEEL, 2005, 18 p.

ANSAR, A.; FLYVBJERG, B.; BUDZIER, A. LUNN, D. Should we build more large dams? The actual costs of hydropower megaproject development. Energy Policy, v. 69, p. 43-56, 2014.

ARTICULAÇÃO DOS POVOS INDÍGENAS DO BRASIL et al. Nota técnica sobre o Projeto Barão do Rio Branco: Nota técnica, Brasília, 2019.

ARCIA-GARIBALDI, G.; CRUZ-ROMERO, P; GÓMEZ-EXPÓSITO, A. Future power transmission: Visions, technologies and challenges. Renewable and Sustainable Energy Reviews, v. 94, p. 285-301, 2018.

AUGÉ, B. Le bassin atlantique: une nouvelle géopolitique des hydrocarbures entre les Amériques et l'Afrique. Hérodote, Paris, n. 155, p. 22-42, 2014.

BALÁŽ, V., \& WILliAMS, A. M. (2007). Path-dependency and Path-creation Perspectives on Migration Trajectories: The Economic Experiences of Vietnamese Migrants in Slovakia. International Migration, 45(2), 37-67. doi:10.1111/j.1468-2435.2007.00403.x

BARBOSA, L. S. et al. Hydropower and power-to-gas storage options: The Brazilian energy system case. Energy Procedia, v. 99, p. 89 - 107, 2016.

BERMANN, C. O projeto da Usina Hidrelétrica Belo Monte: a autocracia energética como paradigma. Novos Cadernos NAEA, v. 15, n. 1, p. 5-23, 2012.

BERNARDI, B. B. O conceito de dependência de trajetória (path dependence): definições e controvérsias teóricas. Perspectivas, São Paulo, v. 41, p. 137-167, 2012.

BRASIL. Ministério de Minas e Energia. Boletim Mensal de Monitoramento do Sistema Elétrico Brasileiro. Brasília: MME, 2020a.

BRASIL. Presidência da República. Decreto n 7.957, de 12 de março de 2013. Diário Oficial da União, Brasília, 13 mar., 2013.

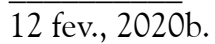

. Decreto $\mathrm{n}^{\circ}$ 10.239, de 11 de fevereiro de 2020. Diário Oficial da União, Brasília,

BRITISH PETROLEUM. BP Statistical Review of World Energy. Londres: BP, 2019.

CAPELLÁN-PÉREZ, I.; CASTRO, C.; ARTOD, I. Assessing vulnerabilities and limits in the transition to renewable energies: Land requirements under 100\% solar energy scenarios. Renewable and Sustainable Energy Reviews, v. 77, p. 760-782, 2017. 
CARVALHO, J. F. Energia e sociedade. Estudos Avançados, São Paulo, v. 28, n. 82, 2014.

CASTRO, C. P. Interligando pobreza e meio ambiente: abordagens comunitárias participativas, jogos de informação imperfeita e a Convenção sobre Diversidade Biológica. Meridiano 47 Journal of Global Studies, v. 18, 2017.

. Le Symbolisme de l'Amazonie dans la presse européenne de la fin du XXe siècle. Paris, Librinova, 2019b.

- "O encontro de Apolo com a floresta: ciencias sociais, ocidentalização do mundo e Amazonia”. Tese de Doutorado, Campinas, Universidade Estadual de Campinas, 2008a, 218 p.

. "O Príncipe e seu Tradutor: Estado, Comunicação e Ambientalismo na Europa". Teoria \& Pesquisa: Revista de Ciência Política, vol. 7, n. 2, pp. 145-170, 2008b.

. "Plantio de grãos em áreas de fronteira, ação antrópica e desmatamento: Estudo do processo de incorporação ao mercado nacional de novas terras da Amazônia”. In: JACOBI, Pedro e FERREIRA, Lúcia. Diálogos em ambiente e sociedade no Brasil. São Paulo: ANPPAS / Anna Blume, 2006, pp. 105-122.

. "Seria a Amazônia uma colônia do Brasil? Ocidente interior, duplo vínculo e governança autônoma”. Crítica e Sociedade: revista de cultura política, vol. 4, no. 2, 2014.

. "Comunicação assimétrica, justiça ambiental e o Protocolo de Consulta Munduruku”. In: GERALDES, E. et al. Resistências e Inovações: Políticas de Comunicação em tempos de crise, Brasíia, FAC Livros - Universidade de Brasília, 2019a.

. "Uma Perspectiva Latino-Americana Sobre os Estudos Amazônicos". In FERREIRA, L. C. (Ed.), A Questão Ambiental Na América Latina: teoria social e interdisciplinaridade. São Paulo: Editora da Universidade Estadual de Campinas, 2011.

CASTRO, C. P., CASTRO, E. and MONTEIRO, R. "Atores sociais na fronteira mais avançada do Pará: São Félix do Xingu e a Terra do Meio". Papers do Naea, n. 180, 2004.

CASTRO C. P. and FERREIRA, L. C. Pensamento norte-americano e processo de incorporação da temática ambiental nas ciências sociais. Revista de Estudos e Pesquisas sobre as Américas, v. 7, n. 2, 2013.

CORRÊA, S. R. Neodesenvolvimentismo e conflitos sociais: o caso da Hidrelétrica de Belo Monte. Novos Cadernos NAEA, v. 19, n. 3, p. 233-254, 2016.

CORREIA, P. P. Manual de geopolítica e geoestratégia. Lisboa: Edições 70, 2018, 843 p.

COWAN, R. Nuclear Power Reactors: A Study in Technological Lock-in. The Journal of Economic History, v. 50, n. 3, p. 541-567, 1990.

COWAN, R.; HULTEN, S. Escaping Lock-In: The Case of the Electric Vehicle. Technological forescating and social change, v. 53, p. 61-79, 1996. 
DAVID, P. A. Clio and the Economics of QWERTY. The American Economic Review, v. 75, n. 2, p. 332-337, 1985.

DELUCCHI, M.; MURPHY, J. US military expenditures to protect the use of Persian Gulf oil for motor vehicles. Energy Policy, n. 36. p. 2253-2264, 2008.

EMPRESA DE PESQUISA ENERGÉTICA. Anuário Estatístico de Energia Elétrica. Brasília: EPE, 2019a, 254 p.

. Brazilian energy balance. Brasília: EPE, 2019b, 303 p.

. Considerações sobre a Expansão Hidrelétrica nos Estudos de Planejamento Energético de Longo Prazo. Brasília: EPE, 2018, 23 p.

FEARNSIDE, P. M. Amazon Dams and Waterways: Brazil's Tapajós Basin Plans. Ambio, v. 44, n. 5, p. 426-39, 2015a.

. Hidrelétricas na Amazônia: impactos ambientais e sociais na tomada de decisões sobre grandes obras. Manaus: Editora do Instituto Nacional de Pesquisas Amazônicas, 2015b, 296 p.

FERREIRA, A. S. Programa Calha Norte (PCN): política pública de segurança, defesa e de desenvolvimento regional no norte do Brasil. In: NASCIMENTO, D. M. Amazônia e defesa: dos fortes às novas conflitualidades. Belém: Editora do Núcleo de Altos Estudos Amazônicos / UFPa, 2010, 267 p.

FLEURY, L. C.; ALMEIDA, J. The construction of the Belo Monte hydroelectric power plant: environmental conflict and the development dilemma. Ambiente $\mathbb{\&}$ Sociedade, São Paulo, v. 16, n. 4, p. 141-158, 2013.

FONTAINE, G. El precio del petróleo: Conflictos socio-ambientales y gobernabilidad en la Región Amazónica. Quito: FLACSO, 2003.

FOUQUET, R. Path dependence in energy systems and economic development. Nature Energy, Vol. 1, p. 1-5, 2016.

FOXON, T. et. al. Branching points for transition pathways: Assessing responses of actors to challenges on pathways to a low carbon future. Energy Policy, v. 52, p. 146-158, 2013.

GULLBERG, A. T. The political feasibility of Norway as the 'green battery' of Europe. Energy Policy, v. 57 p. 615-623, 2013.

HACHE, E. La géopolitique des énergies renouvelables: amélioration de la sécurité énergétique et / ou nouvelles dépendances? Revue internationale et stratégique, n 101, p. 36 - 46, 2016.

HÖGSELIUS, P.; KAIJSER, A. Energy dependence in historical perspective: The geopolitics of smaller nations. Energy Policy. v. 127, p. 438-444, 2019. 
HUBER, M. T. Energizing historical materialism: Fossil fuels, space and the capitalist mode of production. Geoforum, v. 40, p. 105-115, 2008.

Fueling Capitalism: Oil, the Regulation Approach, and the Ecology of Capital. Economic Geography, v. 89, p. 171-194, 2013.

HUNT, J. D. et al. Global resource potential of seasonal pumped hydropower storage for energy and water storage. Nature Communications, v. 11, n. 947, p. 1-8, 2020.

IMMENDOERFER, A. Life-cycle impacts of pumped hydropower storage and battery storage. International Journal of Energy and Environmental Engineering, v. 8, p. 231-245, 2017.

INTERNATIONAL RENEWABLE ENERGY AGENCY. Global energy transformation: A roadmap to 2050. Abu Dhabi, IRENA, 2019.

MATUTINOVIĆ, I. Oil and the political economy of energy. Energy Policy, v. 37, p. 42514258, 2009.

MOHAPATRA, N. K. Energy security paradigm, structure of geopolitics and international relations theory: from global south perspectives. GeoJournal, v. 82, p. 683-700, 2017.

MOORE, J. The Modern World-System as environmental history? Ecology and the rise of capitalism. Theory and Society, v. 32, p. 307-377, 2003.

NASCIMENTO, S. M; CASTRO, E. M. R de. Estado de exceção como paradigma do desenvolvimento: uma análise sobre a hidrelétrica de Belo Monte. In: CASTRO, E. M. R. de (Org.) Territórios em transformação na Amazônia - saberes, rupturas e resistências. Belém: Editora do Núcleo de Altos Estudos Amazônicos / UFPa, 2017.

NICOLINI, M.; TAVONI, M. Are renewable energy subsidies effective? Evidence from Europe. Renewable and Sustainable Energy Reviews, v. 74, p. 412-423, 2017.

OVERLAND, I. The geopolitics of renewable energy: Debunking four emerging myths. Energy Research \& Social Science, v. 49, p. 36-40, 2019.

PALTSEV, S. The complicated geopolitics of renewable energy. Bulletin of the atomic scientists, v. 72, n. 6, p. 390-395, 2016.

PHUANGPORNPITAK, N.; TIA, S. Opportunities and Challenges of Integrating Renewable Energy in Smart Grid System, Energy Procedia, v. 34, p. 282 - 290, 2013.

PROST, C. Forças armadas, geopolítica e Amazônia. Papers do NAEA, Belém, n. 156, 2000.

RAMAN, S. Fossilizing Renewable Energies. Science as Culture, v. 22, n. 2, p. 172-180, 2013.

RAVENA, N. et al. Política e estratégias de integração na Pan-Amazônica: qual o lugar da agenda ambiental? Desenvolvimento em Debate, v.7, n.1, p.133-159, 2019) 
RUOTSALAINEN, J. et. al. Culture, values, lifestyles, and power in energy futures: A critical peer-to-peer vision for renewable energy. Energy Research \& Social Science, v. 34, p. 231-239, 2017.

RUTTAN, Vernon. Induced innovation, evolutionary theory and path dependence: sources of technical change. The Economic Journal, v. 107, p. 1520-1529, 1997.

SCHOLTEN, D.; BOSMAN, R. The geopolitics of renewables; exploring the political implications of renewable energy systems. Technological Forecasting $\&$ Social Change, v. 103, p. 273-283, 2016.

SULLIVAN, M. O.; OVERLAND, I.; SANDALOW, D. The Geopolitics of Renewable Energy. Harvard Kennedy School Working Paper, n. 27, 2017.

TAVARES, M. G., COELHO, M. C.; MACHADO, L. O. Redes de distribuição de energia e desenvolvimento regional na Amazônia Oriental. Novos Cadernos NAEA, v. 9, n. 2, p. 99-134, 2006.

VAKULCHUK, R.; OVERLAND, I.; SCHOLTEN, D.. Renewable energy and geopolitics: A review. Renewable \& Sustainable Energy Reviews, v. 122, p. 1-12, 2020.

WORLD RESOURCES INSTITUTE. Watersheds of the world. Washington: WRI, 2005. 


\section{Carlos Potiara Castro}

$\varangle$ carlospotiara@gmail.com

ORCiD: https://orcid.org/0000-0002-0493-6397
Submitted on: 29/05/2020

Accepted on: 24/02/2021

2021;24e:01291

How to cite: CASTRO, C. P. Hydropower and the geopolitics of renewable energies in the Amazon Basin. Ambiente \& Sociedade. São Paulo, v. 24, p. 1-20, 2021. 


\title{
Hidrelétricas e a geopolítica das energias renováveis na Amazônia
}

\author{
Carlos Potiara Castro
}

São Paulo. Vol. 24, 2021

Artigo Original
Resumo: Este artigo objetiva realizar uma reflexão em torno importância estratégica da energia hidrelétrica gerada na região amazônica para o sistema nacional interligado. Sua quantificação mostra que há um potencial regional de geração de energia superior em importância à produção atual de petróleo do pré-sal. Neste estudo, considera-se a questão sob a ótica da geopolítica das energias renováveis, que traz um conjunto de elementos novos e relevantes para o tema. O quadro analítico deste artigo centra na dependência de trajetória, nas redes inteligentes e nas sociedades energo-intensivas e suas políticas de segurança energética. Conclui-se que, na configuração atual, o advento das energias renováveis pode constituir elemento adicional de uma especialização econômica de longo prazo da Amazônia, com consequências preocupantes na perspectiva socioambiental.

Palavras-chave: Dependência de trajetória; Políticas de segurança energética; Sociedades energo-intensivas; Região amazônica

Como citar: CASTRO, C. P. Hidrelétricas e a geopolítica das energias renováveis na Amazônia. Ambiente \& Sociedade. São Paulo, v. 24, p. $1-20,2021$.

DOI: http://dx.doi.org/10.1590/1809-4422asoc20200129r1vu2021L2AO 


\title{
Hidroeléctricas y la geopolítica de las energías renovables en la Amazonía
}

\author{
Carlos Potiara Castro
}

São Paulo. Vol. 24, 2021

Artículo original
Resumen: Este artículo tiene como objetivo reflexionar sobre la importancia estratégica de la energía hidroeléctrica generada en la región amazónica para el sistema nacional interconectado. Su cuantificación muestra que existe un potencial regional de generación de energía superior a la producción actual de petróleo pre-sal. En este estudio, el tema es considerado desde la perspectiva de la geopolítica de las energías renovables, lo que aporta un conjunto de elementos nuevos y relevantes al tema. El marco analítico de este artículo se centra en la dependencia de la trayectoria, las redes inteligentes y las sociedades intensivas en energía y sus políticas de seguridad energética. Se concluye que, en la configuración actual, el advenimiento de las energías renovables puede constituir un elemento adicional de especialización económica a largo plazo en la Amazonía, con preocupantes consecuencias en la perspectiva socioambiental.

Palabras-clave: Dependencia de la trayectoria; Políticas de seguridad energética; Sociedades intensivas en energía; Región amazónica.

Como citar: CASTRO, C. P. Hidroeléctricas y la geopolítica de las energías renovables en la Amazonía. Ambiente $\&$ Sociedade. São Paulo, v. 24, p. 1-21, 2021.

DOI: http://dx.doi.org/10.1590/1809-4422asoc20200129r1vu2021L2AO 